\title{
Optimization of Forest Ecosystem Recreational Services Formation in Conditions of Decentralization in Ukraine
}

\author{
Oleksiy Holubchak \\ director \\ Ukrainian Research Institute of \\ Mountain Forest named after \\ P. S. Pasternak \\ Ivano-Frankivsk, Ukraine \\ https://orcid.org/0000-0001-7817-1940
}

\author{
Svitlana Korol* \\ Department of Finances \\ Ivano-Frankivsk National Technical \\ University of Oil and Gas \\ Ivano-Frankivsk, Ukraine \\ https://orcid.org/0000-0002-4804-7612 \\ Mykola Prykhodko \\ Department of Geodesy and Land \\ Management \\ Ivano-Frankivsk National Technical \\ University of Oil and Gas \\ Ivano-Frankivsk, Ukraine \\ prihodkon@ukr.net
}

\author{
Ivanna Melnychuk \\ Department of Applied Economics \\ Ivano-Frankivsk National Technical \\ University of Oil and Gas \\ Ivano-Frankivsk, Ukraine \\ https://orcid.org/0000-0003-3425-2575
}

\begin{abstract}
One of the main conditions for increasing the level of ecosystem service delivery through the prism of decentralization is in-depth analysis and monitoring of the state of ecosystems, which will allow the development of priority services on a fee basis. The article shows the influence of the integrated territorial communities (ITC) on the activities of the territorial and recreational system, which allowed to optimize the costs of recreation facilities. The classification of forest ecosystem services according to the evaluation indicators has been systematized. From a practical point of view, the model of the optimal functioning organization of the recreational object was adapted, which was preceded by the analysis of forestry, which allowed to determine the capacity of a single recreational load. The model of recreational object optimum functioning organization on the example of forestry was built, which allows to increase the recreation on the objects of recreation. A descriptive model of the recreational area, the key object of which is the complex of ecosystem services of forest located in the territory of the ITC is proposed. Its structure offers the arrangement of recreation rooms in the territory of the forestry for temporary stay, which will allow to generate income. The issue of income in the part of recreation is quite painful, since recreational places are free for recreation.
\end{abstract}

Keywords-recreation, forestry, recreational load, integrated territorial community, recreational territory

\section{INTRODUCTION}

Within the framework of decentralization reform in Ukraine through the creation of ITC, there is an opportunity to increase the level of ecosystem services. First, through the analysis and control of the state of ecosystems in the territory of the association, as well as independently identify and develop priority ecosystem services on a fee basis. ITC is an administrative-territorial unit, which is a new link in the system of administrative system in Ukraine and is intended to improve the provision of administrative services to the population, optimize the management of local property. Voluntary association of territorial communities is regulated by the Law of Ukraine "On Voluntary Association of Territorial Communities" adopted in 2015. The adoption of this Law was preceded by the ratification of the European Charter of Local Self-Government by Ukraine, as well as the adoption of a number of legal acts that delineated and established the powers of individual regions of the state. In particular, such acts were the Constitution of the Autonomous Republic of Crimea, the Law of Ukraine "On Local State Administrations", and the Law of Ukraine "On Local Self-Government in Ukraine".

Studying the experience of European countries, we can conclude that in Sweden, Poland, Spain, Denmark and other countries, decentralization occurred through the consolidation of territorial communities, which was carried out both through voluntary association of territorial communities and administratively - through decision-making by central government bodies after the deadline for voluntary association $[1 ; 2 ; 3]$. However, the current decentralization process in Ukraine is complicated by a set of elements that are linked to the phased implementation of variable components that have a direct impact on the results of the decentralization reform. Not only positive results, but also the level and life quality of the population depend on the effective allocation of financial resources. The problem of decentralization, with a focus on detailing practical aspects, has not been sufficiently explored, since at the beginning of 2014 it has become a promising one. In today's context, it is gaining momentum, providing a broad field of activity for its further exploration with the use of foreign experience [4]

As noted above, one of the reasons for creating an ITC is to optimize property management, so it would be appropriate to emphasize that the European Community has focused on the degradation of more than 2 billion hectares of ecosystem services over 60 billion hectares over the last forty years. the degraded and deforested lands of the planet have lost the ability to benefit people and other species, and their 
restoration is one of the global priorities $[5 ; 6]$. Therefore, let us try to analyze the ecosystem services of the forest system of a certain area and to develop recommendations and directions for improving their condition. The purpose of the article is to optimize the formation of recreational forest ecosystem services in the context of decentralization in Ukraine.

\section{MATERIALS AND MethodS}

The concept of ecosystem services (ES) remains underused in supporting practical decisions in conservation / development plans and programs. One of the most important factors explaining this non-consideration is the lack of information describing the nature-society relationship in environmental and economic analyses [7]. Foreign scientists define ecosystem services as "a set of ecosystem functions that are beneficial to humans" [8; 9]. They are the result of auxiliary processes operating on different time and space scales of [10]. The definition of the UN Millennium Ecosystem Assessment (MEA 2003), which has been widely used in international scientific research, emphasizes the close link between ecosystem services and the benefits generated directly or indirectly by environmental systems for humans. Forest ecosystem services play an important role in ecosystem services. Besides traditional timber production, other forest functions, such as biodiversity and recreation, have gained increasing importance during the last few decades. Demands on forests have become more diversified, thus making forest management and planning more complex. To meet these challenges, there is a growing interest in a more diversified silviculture, for which a number of different management options are available [11].

It is the recreational services of the forest ecosystem that should be viewed through the lens of maximum interaction between the recreation and the forest. If on the one hand the forest has a passive effect on the recreation, on the other the recreation influences actively. Since the forest is used for various purposes in the process of use, it is advisable to first classify the forest. In particular, in accordance with the order of division of forests into categories and the allocation of especially protected forest areas, it is established that forests, depending on their main functions, are divided into the following categories: forests of nature, scientific, historical and cultural purpose; recreational and recreation forests; protective forests; operating forests. In this case, forest ecosystem services can be classified into specific groups (Table 1).

Depending on the forest category, each of the services has its own purpose and is characterized by a set of evaluation indicators. Among all types of forests, recreational and recreational forests in particular require more detailed analysis, since they do not generate income from forestry use, but instead incur a considerable amount of costs that are necessary for the establishment of recreational sites. The cost component is the basis for further analysis and recommendations for improving recreational services. Since one of the most important problems of organizing a territorial-recreational system (TRS) is the problem of rational use of recreational resources, as well as the maximum satisfaction of the interests of all participants of this process, it is advisable to build a model of organization of optimal functioning of a recreational object on the example of forestry.

\section{TABLE I. CLASSIFICATION OF FOREST ECOSYSTEM SERVICES}

\begin{tabular}{|c|c|c|c|}
\hline $\begin{array}{c}\text { Classification } \\
\text { feature }\end{array}$ & Characteristic & $\begin{array}{l}\text { Types of } \\
\text { services }\end{array}$ & $\begin{array}{c}\text { Evaluation } \\
\text { indicators }\end{array}$ \\
\hline securing & $\begin{array}{lr}\text { services } & \text { from } \\
\text { products } & \text { provided } \\
\text { by } & \text { forest } \\
\text { ecosystems } & \end{array}$ & $\begin{array}{l}\text { wood, game, } \\
\text { clean water, } \\
\text { bio-energy raw } \\
\text { materials, } \\
\text { crops, genetic } \\
\text { material }\end{array}$ & \multirow{4}{*}{ 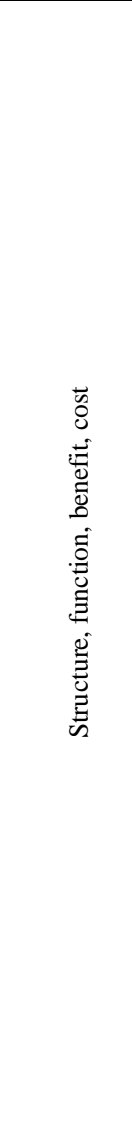 } \\
\hline adjusting & $\begin{array}{lr}\text { services } & \text { of } \\
\text { regulating } & \text { forest } \\
\text { ecosystem } & \\
\text { processes } & \end{array}$ & $\begin{array}{l}\text { climate } \\
\text { control, } \\
\text { nitrogen } \\
\text { absorption, air } \\
\text { quality, noise } \\
\text { reduction, } \\
\text { water } \\
\text { treatment, } \\
\text { erosion control } \\
\end{array}$ & \\
\hline cultural & $\begin{array}{l}\text { the contribution of } \\
\text { the forest } \\
\text { ecosystem to the } \\
\text { enrichment of } \\
\text { cultural, spiritual } \\
\text { and aesthetic } \\
\text { aspects of well- } \\
\text { being population: } \\
\text { emotional state }\end{array}$ & $\begin{array}{l}\text { recreation, } \\
\text { ecotourism, } \\
\text { cultural } \\
\text { heritage, } \\
\text { landscapes, } \\
\text { arts and } \\
\text { popular science } \\
\text { culture, solion } \\
\text { and education }\end{array}$ & \\
\hline supportive & $\begin{array}{l}\text { services designed to } \\
\text { provide other } \\
\text { ecosystem services }\end{array}$ & $\begin{array}{l}\text { Water } \\
\text { retention, soil } \\
\text { quality, } \\
\text { nutrient } \\
\text { retention, } \\
\text { adsorption of } \\
\text { waste and } \\
\text { toxins, } \\
\text { breeding } \\
\text { habitats, } \\
\text { pollination }\end{array}$ & \\
\hline
\end{tabular}

The most adequate model of organization of optimal functioning is presented by the author in work [12]. We consider it appropriate to adapt it to the territorialrecreational system.

Let the TRS consist of $\mathrm{m}$ territorial-recreational objects (TRO) of service, whose recreations are divided into $\mathrm{n}$ types. We use the following notation:

$-x_{i}^{(j)}$ - the number of recreants $j$ type in TRO $i$;

$x^{-(j)}=\left(x_{1}^{(j)}, \ldots, x_{m}^{(j)}\right)^{\prime}$ - the desired vector of the number of recreants type $j$;

$-(\mathrm{j}=\overline{1, n})$ placed in TRO service and $(\mathrm{i}=\overline{1, m})$;

$-\mathrm{A}^{(\mathrm{j})}$ - the size matrix $\left(\mathrm{m}^{*} \mathrm{~m}\right)$, each element $a_{i^{\prime} i}^{(j)}$, which is the probability that the recreant $j$ type TRO $i^{\prime}$ will move to TRO and in the next period of time;

$-\mathrm{B}^{(\mathrm{k}, \mathrm{j})}$ - dimension matrix $(\mathrm{m} * \mathrm{~m})$, each element of which $b_{i^{\prime} i}^{(k, j)}$ - is the value of type services $k$ at the point $i^{\prime}$, that the visitor needs $j$ the type that is in the item (TRO) $i$; 
${ }_{-} c^{-(k)}=\left(c_{1 k, \ldots .,} c_{m k}\right)^{\prime}$ - content vector TRO and for $\mathrm{k}$ type services;

$-\mathrm{K}$ - number of services in the TRS;

- $\mathrm{d}_{\mathrm{i}}^{(\mathrm{j})}$ - maximum demand of $\mathrm{j}$-type recreation for services TRO $i$.

Then the model of organizing the optimal functioning of the TRS will take the form:

$$
\left\{\begin{array}{l}
\max \sum_{i=1}^{m} \sum_{j=1}^{n} x_{i}^{(j)} \\
x^{-(j)}=A^{(j)} x^{-(j)}, \quad j=\overline{1, n} \\
\sum_{j=1}^{n} B^{(k, j)} x^{-(j)} \leq c^{-(k)}, \quad k=\overline{1, k}, \\
x_{i}^{(j)} \leq d_{i}^{(j)}, \quad i=\overline{1, m}, \quad k=\overline{1, k}, \quad j=\overline{1, n .}
\end{array}\right.
$$

It is easy to see that in this model the total number of TRS recreants is maximized.

The ratio states that the number of recreations of each type in the TRS is equal to the sum of the part that remained there from the previous period and those that came from other points.

\section{RESULTS}

For the purpose of detailed analysis, the object of the study will be selected the most forested Dolyna region, in particular SE "Vygoda forestry" [13]. Forestry is managed through the mobilization of own funds. At the same time, the main activities of the enterprise are forestry, protection, protection, rational use and reproduction of forests, protection of forest plantations against illegal logging, implementation of fire-fighting measures, protection of forests from diseases and pests in order to conserve biodiversity, protection, reproduction and rational use of state hunting fund, development of forest infrastructure (construction and repair of forest roads, bridges), improvement of working conditions and increase of salaries of employees, increasing budget revenues at all levels.

The forest management of SE "Beneficial Forestry" is carried out in accordance with the certification, created by FSC® (Forest Stewardship Council®) - Forest Stewardship Council, - the international organization of responsible forest management. It was created by representatives of 25 countries in 1993 in response to the threat of global deforestation [14]. SE "Vygoda Forestry" is certified according to the standard Single Forest Management and Chain of Custody, Certificate registration code NC-FM / COC-013427, FSC® License Code FSC® C108277. The selection of sites in the category of particular value for the conservation of forests (paragraph 9 of FSC® certification of forests) took into account the SE "Vygoda Forestry" forests structure and their functional role. One of the certification objectives is monitoring, which covers all implementation issues, efficiency and verification at the company, in principle, as expected when developing certification for forestry [15].
The company is represented by 12 forestry units, each of which belongs to the respective village council or ITC. The forestry is divided into parts, in particular the forest quarters and the section. SE "Vygoda Forestry" has in its structure forests of nature, scientific, historical and cultural purpose, occupying an area of $6072.2 \mathrm{ha}$; recreational and recreational forests - 2840,9 ha; protective forests - 23003.5 ha; operating forests - 28012,2 ha. As a result, the company has five village councils and one ITC, to which certain forests are concerned, including:

- Shevchenkivsk village council (6 forestries);

- Obolonsk village council (1 forestry);

- Pidliskivsk Village Council (1 forestry);

- Lolynsk village council (1 forestry);

- Maloturyansk village council (1 forestry);

- Vygoda ITC (there are 7 former village and village councils within the ITC) (8 forestries).

Each of the forestry located in the territory of SE "Vygoda Forestry" has recreation facilities, which in turn have the capacity of a single recreational load (maximum number of people), which is indicated in Fig 1.

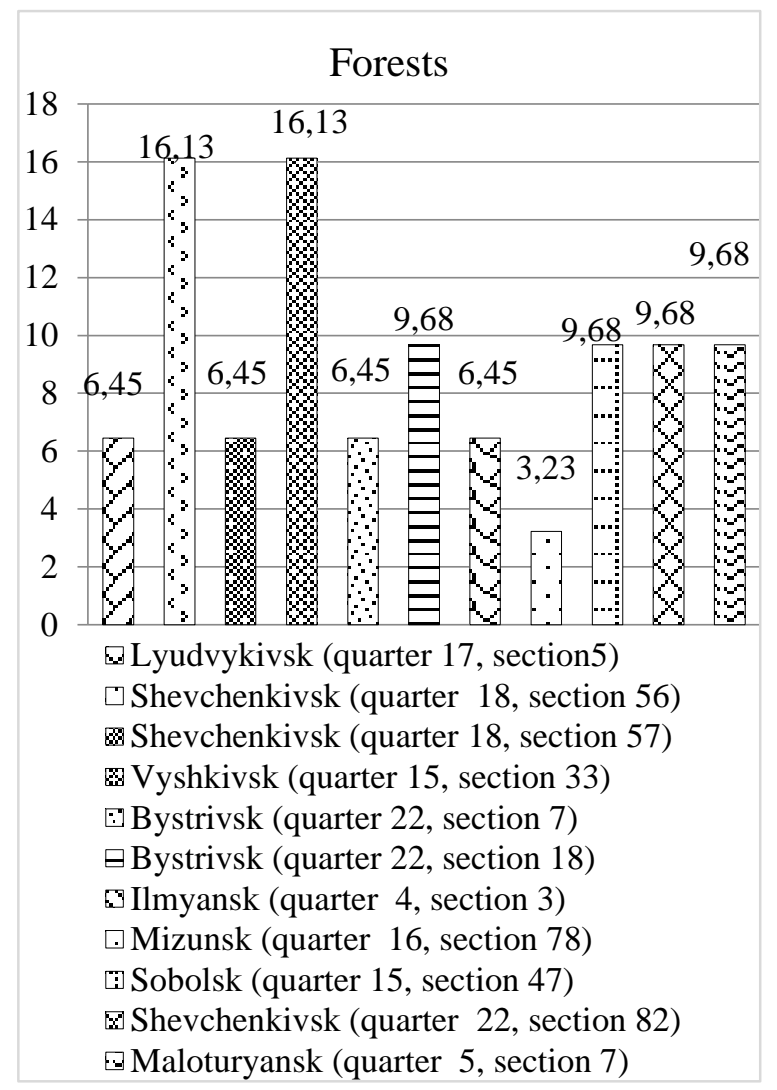

Fig. 1. Throughput of one-time recreational load (maximum permissible number of persons, \%) of SE "Vygoda Forestry" as of 2019

The above indicates that Shevchenkivsk (quarter 18 section 56) and Vyshkivsk (quarter 15 section 33), which is the maximum number of forestry, which is the maximum share in the relative structure of the capacity of one-time recreational load of SE "Vygoda Forestry" in the amount of $16.13 \%$ (50 people) in each of them. The Shevchenkivsk 
forestry has membership in the village council, and the Vyshkivsk forestry belongs to the Vygoda forestry. For comparison, let's analyze the costs of recreational sites between the two forests (Table 2).

Costs for the arrangement of recreational sites for individual forestry of SE "Beneficial Forestry"

TABLE II. COSTS FOR ARRANGEMENT OF RECREATIONAL SITES FOR INDIVIDUAL FORESTRY OF SE "VYGODA FORESTRY”

\begin{tabular}{|l|c|c|c|}
\hline \multirow{2}{*}{ Indexes } & \multicolumn{2}{|c|}{ Types of forestry } & \\
\cline { 2 - 4 } & $\begin{array}{c}\text { Vyshkov } \\
\text { (ITC) }\end{array}$ & $\begin{array}{c}\text { Shevchenkov } \\
\text { (village council) }\end{array}$ & $\begin{array}{c}\text { Deviation (c/p / } \\
\text { ITC), +/- }\end{array}$ \\
\hline $\begin{array}{l}\text { Direct costs, } \\
\text { UAH }\end{array}$ & 13712,29 & 607969,8 & $+594257,51$ \\
\hline $\begin{array}{l}\text { Production } \\
\text { costs, UAH. }\end{array}$ & 2169,94 & 40000,3 & $+37830,36$ \\
\hline $\begin{array}{l}\text { Total expenses, } \\
\text { UAH. }\end{array}$ & 15882,23 & 647970,2 & $+632087,97$ \\
\hline $\begin{array}{l}\text { Including } \\
\text { materials, UAH }\end{array}$ & 3848,17 & 349222,5 & $+345374,33$ \\
\hline $\begin{array}{l}\text { Total estimated } \\
\text { wages, UAH. }\end{array}$ & 9864,12 & 144008,3 & $+134144,18$ \\
\hline $\begin{array}{l}\text { Total labor } \\
\text { cost, man / } \\
\text { hour. }\end{array}$ & 614,38 & 5666 & $+5051,62$ \\
\hline Total, UAH & 15882,23 & 647970,2 & $+632087,97$ \\
\hline
\end{tabular}

The calculations indicate that the recreation facilities located in the territory of Shevchenkivsk Forestry with belonging to the village council use a much larger amount of expenses than the object located in the territory of the ITC, which in total amounted to an excess of $+632087,97 \mathrm{UAH}$ This in turn is an indication of the cost optimization associated with the implementation of decentralization reform. Taking into account the obtained results, it is advisable to build a model of organization of optimal functioning of the recreational object on the example of the State Enterprise "Vygoda Forestry".

TRS SE "Vygoda Forestry" consists of 11 TRO services, whose recreation is divided into 4 types.

The initial data for the construction of the model of organization of optimal functioning of the TRS are shown in Table. 3.

TABLE III. BASELINE DATA FOR THE CONSTRUCTION OF THE MODEL OF ORGANIZATION OF OPTIMAL FUNCTIONING OF THE TPP OF SE "VYGODA FORESTRY"

\begin{tabular}{|c|c|c|c|c|c|c|}
\hline \multirow{2}{*}{ TPO $\boldsymbol{i}$} & \multicolumn{7}{|c|}{ Indexes } \\
\cline { 2 - 7 } & $x_{i}^{(j)}$ & $x^{-(j)}=\left(x_{1}^{(j)}, \ldots, x_{m}^{(j)}\right)^{\prime}$ & $\overline{\mathbf{j}=n}$ & $c^{-(k)}=\left(c_{1 k, \ldots .,} c_{m k}\right)^{\prime}$ & $\boldsymbol{K}$ & $\boldsymbol{d}_{i}^{(j)}$ \\
\hline 1 & 20 & 18 & 1 & 4 & 3 & 25 \\
\hline 2 & 50 & 46 & 3 & 5 & 4 & 80 \\
\hline 3 & 20 & 19 & 4 & 3 & 2 & 30 \\
\hline 4 & 50 & 47 & 3 & 4 & 3 & 90 \\
\hline 5 & 20 & 15 & 2 & 3 & 2 & 35 \\
\hline 6 & 30 & 29 & 3 & 5 & 5 & 40 \\
\hline 7 & 20 & 18 & 1 & 4 & 3 & 28 \\
\hline 8 & 10 & 9 & 4 & 5 & 3 & 23 \\
\hline 9 & 30 & 28 & 3 & 3 & 2 & 41 \\
\hline 10 & 30 & 27 & 3 & 5 & 3 & 36 \\
\hline 11 & 30 & 28 & 3 & 5 & 5 & 48 \\
\hline
\end{tabular}

The data indicate that the maximum demand for recreation can reach 48 people, with a planned number of 25 people, which is possible with the maximum provision of recreational services.
Next, it is necessary to construct appropriate matrices, in the first of which each element is the probability that the recreation will move from one recreational object to another at the next visit. This probability is possible with the maximum receipt of all recreational services. The second matrix makes it possible to determine the amount of services needed by the visitor at the point of recreation. Matrix $\mathrm{A}^{(\mathrm{j})}$ SE "Vygoda Forestry" will look like:

$$
a_{i^{\prime} i}^{(j)}=\left[\begin{array}{l}
1234 \\
2341 \\
3412 \\
4123
\end{array}\right]
$$

Matrix B ${ }^{(k, j)}$ SE "Vygoda Forestry” will look like this:

$$
b_{i^{\prime} i}^{(k, j)}=\left[\begin{array}{l}
4344 \\
3223 \\
4223 \\
2123
\end{array}\right]
$$

Therefore, the model of organization of optimal functioning of the TPP of SE "Vygoda Forestry" will look like:

$$
\left\{\begin{array}{l}
\max \sum_{i=1}^{46} \sum_{j=1}^{4} x_{50}^{(4)} \\
x^{-(j)}=A^{(j)} x^{-(j)}, \\
\sum_{j=1}^{n} B^{(k, j)} x^{-(j)} \leq c^{-(k)}, \\
50 \leq 90, \quad i=\overline{1,2,3,4,5,6,7,8,9,10,11}, \\
k=\overline{1,2,3,4,5,} \quad j=\overline{1,2,3,4 .} .
\end{array}\right.
$$

Since the condition at which $50 \leq 90$ is fulfilled, it indicates that the model is correctly formed and verifiable. At the same time, the calculations show the maximization of recreation at the recreation facilities of SE "Vygoda Forestry".

\section{CONCLUSIONS AND RECOMMENDATIONS}

Recreational resources are an essential part of the Carpathian natural potential. Taking into account that the territory of SE "Vygoda Forestry" is completely located in the mountainous area, the administration is constantly creating new recreational places for recreation of autotourists, young people and children. They are designed to meet a variety of recreational needs. The calculations made it possible to understand that the TRS should ensure that the needs of the population are met in recreation, health, entertainment, physical, cultural and aesthetic development. Each of the forests has recreational places in its structure, which are constantly updated and new ones are created. At the same time, those recreational facilities that are within the ITCs require significantly less costs than those related to the village councils, which are caused by the lack of costs for the general contractors, since many works are performed by themselves. 
However, the bandwidth of a single recreational load when constructing a model of optimal ITCs operation indicates that it can be significantly increased with parallel cost optimization. This can be achieved by maximizing the utilization of recreational facilities without the extra cost, which is a realistic scenario in an ITC. As a result of the analysis of the objects of recreation and the model of the organization of optimal functioning of the ITC, we recommend a descriptive model of the recreational territory, the key object of which is the complex of ecosystem services of the forest located in the territory of the ITC. Its structure includes: visits to historical and cultural monuments, places of entertainment, camping, hotels, sports recreation, melting on the river, Carpathian tours, organization of recreation directly in the forest, recreation on the river bank, recreational facilities, hiking, gaming playgrounds, sandboxes, parking; we recommend that you arrange recreation rooms in the forested area for temporary stay on a paid basis.

\section{REFERENCES}

[1] L. Moreno, The Federalization of Spain - London, Portland, OR: Frank Cass, 2001

[2] E. Ruśkowski, J. Salachna, Finanse lokalne po akcesji, Warszawa: Wolters Kluwer Polska Sp. z o.o., 2007.

[3] O. Borislavska, I. Zaverukha, E. Zakharchenko, and others, «Decentralization of public power: experience of European countries and prospects of Ukraine», Swiss-Ukrainian project «Support for decentralization in Ukraine», K.: DESPRO Sofia LLC. 2012. [in Ukrainian].

[4] O. Holubchak, L. Horal, S. Korol, «The research of theoretical and practical aspects of decentralization as a new management system in Ukraine», Technology audit and production reserves, Kharkiv: SPC PC «Technology center», no. 6 (44), pp. 4-10, 2018. doi 10.15587/2312-8372.2018.149673.

[5] IUCN, Forest Landscape Restoration, 2015. [Online]. Available: https://www.iucn.org/theme/forests/our-work/forest-landscaperestoration. Accessed on: September 25, 2016
[6] United Nations (UN), Forest action statements and action plans. 2014. [Online]. Available: http://www.rff.org/centers/management_of_ecological_wealth/Pages/ Forest-ConservationTargeting-Tool.aspx. Accessed on: September 25, 2016.

[7] Tardieu, Léa \& Tuffery, Laetitia, «From supply to demand factors: What are the determinants of attractiveness for outdoor recreation?», Ecological Economics, no. 161, pp. 163-175, 2019. doi: 10.1016 / j.ecolecon.2019.03.022

[8] C. Kremen, , \& R. Cowling, «Managing ecosystem services: what do we need to know about their ecology?», Ecology Letters, no. 8 (5), pp. 468-479, 2005. doi:10.1111/j.1461-0248.2005.00751.x

[9] McMichael, Anthony, Scholes, Robert, Hefny, Manal, Pereira, Elvira, Palm, Cheryl, and Foale, Simon, Linking ecosystem services and human well-being. In: Capistrano, Doris, Samper K., Cristián, Lee, Marcus J., and Raudsepp-Hearne, Ciara, (eds.) Ecosystems and Human Well-being: multi-scale assessments. MIllenium Ecosystem Assessment Series, 4. Island Press, Washington DC, USA, pp. 43-60. 2005.

[10] S. Farber, R. Costanza, , D. L. Childers, J. Erickson, K. Gross, M. Grove, C. S. Hopkinson, J. Kahn, S. Pincetl, A. Troy, P. Warren and M. Wilson, «Linking Ecology and Economics for Ecosystem Management», BioScience, no. 56, pp. 121-133, 2006. doi.org/10.1641/0006-3568(2006)056[0121:LEAEFE]2.0.CO;2

[11] Eggers, Jeannette \& Holmgren, Sara \& Nordström, Eva-Maria \& Lämås, Tomas \& Lind, Torgny \& Öhman, Karin, «Balancing different forest values: Evaluation of forest management scenarios in a multicriteria decision analysis framework», Forest Policy and Economics. Elsevier, vol. 103 (C), pp. 55-69, 2019.

[12] I. M. Shkola, O. P. Korolchyk, Tourism Management: A Handbook, Chernivtsi: Books-XXI, 2011. [in Ukrainian].

[13] Website of SE "Vygoda Forestry", 2019. [Online]. Available: http://www.vygodalis.com, free. Accessed on: August 6, 2019. [in Ukrainian].

[14] Forest Stewardship Council. Global FSC certificate type and distribution, 2012. [Online]. Available: http://www.fsc.org/factsfigures.19.htm. Accessed on: August 4, 2019.

[15] E. Meijard, S. Wunder, M. Guariguata, D. Sheil, «What scope certifying forest ecosystem services?», Ecosystem Services, vol. 7, pp. 160-166, 2014 